\title{
RANCANG BANGUN PENGHITUNG BENIH IKAN MENGGUNAKAN BINARY THRESHOLDING PADA RASPBERRY PI SECARA REAL TIME
}

\author{
Rosa Andrie A. ${ }^{1}$, Irawati Nurmala Sari ${ }^{2}$, Vivid Ichtarosa Arinda ${ }^{3}$ \\ 1,2,3 Program Studi Teknik Informatika, Jurusan Teknologi Informasi, Politeknik Negeri Malang \\ ${ }^{1}$ rosa.andrie@polinema.ac.id, ${ }^{2}$ irawati.polinema@gmail.com, ${ }^{3}$ vividarinda@gmail.com
}

\begin{abstract}
Abstrak
Benih yang baru dipanen biasanya akan menurun kondisinya. Untuk memulihkannya ada beberapa cara salah satunya adalah menampung benih di dalam wadah penampungan sementara ketika panen dilakukan. Selain ditampung, benih juga harus dihitung untuk mengetahui jumlahnya. Perhitungan juga harus dilakukan dengan cepat dan tepat agar benih tidak menjadi lemah, lalu mati. Selama ini petani ikan masih melakukan perhitungan benih secara manual yaitu dengan menghitung satu per satu atau menggunakan volume (gelas). Sehingga selain memakan waktu yang lama, benih ikan terkadang stress dikarenakan perhitungan yang masih manual. Penelitian ini mendesain dan mengembangkan alat yang mampu menghitung benih ikan dengan mengimplementasikan pengolahan citra sebagai solusi untuk mengatasi permasalahan para petani ikan. Sistem yang dirancang dan diimplementasikan menggunakan HTML, Python, serta pengolahan citra yang menggunakan metode Thresholding, Morphology, serta pelabelan. Sistem ini diterapkan secara real time, serta dapat menghitung objek yang mendekati perhitungan yang sebenarnya. Sistem ini telah diuji menggunakan 4 data set yaitu benih yang diuji tiap kelipatan 10 dan berakhir pada pengujian 40 benih ikan. Tingkat keakuratan tertinggi mencapai $99.9977 \%$ untuk pengujian perhitungan 40 benih.
\end{abstract}

Kata Kunci : Image Processing, Benih Ikan, Petani Ikan

\section{Pendahuluan}

Ikan merupakan bahan pangan yang banyak dikonsumsi oleh manusia sejak beberapa abad yang lalu karena selain mengandung protein, ikan kaya akan gizi yang baik untuk kembang tulang tubuh. Selain mudah didapat, ikan memiliki harga yang terjangkau. Indonesia sendiri merupakan salah satu wilayah yang mengkonsumsi ikan dan menjadi bahan pangan pokok yang banyak dijual. Setiap hari beredar berton-ton ikan yang dipanen dari keramba jaring apung di sana. Permintaan kebutuhan masyarakat akan ikan terus meningkat dari tahun ke tahun. Produksi ikan di Indonesia harus didukung oleh benih yang unggul dan berkelanjutan. Oleh karena itu, salah satu bidang usaha perikanan yang bisa dipilih adalah segmen pembenihan Usnie Arie, dkk (2013).

Benih yang baru dipanen biasanya akan menurun kondisinya. Untuk memulihkannya ada beberapa cara salah satunya adalah menampung benih di dalam wadah penampungan sementara ketika panen dilakukan. Selain ditampung, benih juga harus dihitung untuk mengetahui jumlahnya. Perhitungan juga harus dilakukan dengan cepat dan tepat agar benih tidak menjadi lemah, lalu mati. Selama ini petani ikan masih melakukan perhitungan benih secara manual yaitu dengan metode sampling atau dengan menghitung satu per satu. Rata-rata petani membutuhkan waktu sekitar 15-20 menit untuk menghitung 1000 benih ikan lele M. Zani Kusuma Adhi (2012).

Sebelumnya telah dilakukan penelitian mengenai "sistem cerdas penghitung sel kulit mati pada manusia dengan metode improved counting morphology" oleh Ahmad Fahrudi Setiawan, Wijoyono, dan Sunaryo (2013) dengan judul skripsi "identifikasi jumlah koloni pada citra bakteri dengan metode improved counting morphology" (2014, Program Studi Informatika atau Ilmu Komputer, Universitas Brawijaya). Penelitian serta skripsi di atas adalah salah satu contoh perhitungan suatu objek dengan menggunakan image processing. Image processing dapat dijadikan alternatif karena metode ini tidak merusak objek (nondestructive).

Berdasarkan latar belakang tersebut, penulis mengangkat sebuah judul "Rancang Bangun Penghitung Benih Ikan Menggunakan Binary Thresholding Pada Raspberry Pi Secara Real Time" sebagai solusi pada permasalahan penghitungan benih ikan tersebut. 


\section{Tinjauan Pustaka}

\subsection{Benih Ikan}

Benih ikan adalah nama sebutan untuk ikan yang baru menetas sampai mencapai ukuran panjang tubuh 5-6 cm Sachlan (1975). Dalam bahasa ilmiah benih ikan yang ditunjukkan pada Gambar 1 secara umum disebut sebagai larva (fish fry), sementara orang awam menamakannya anak ikan.

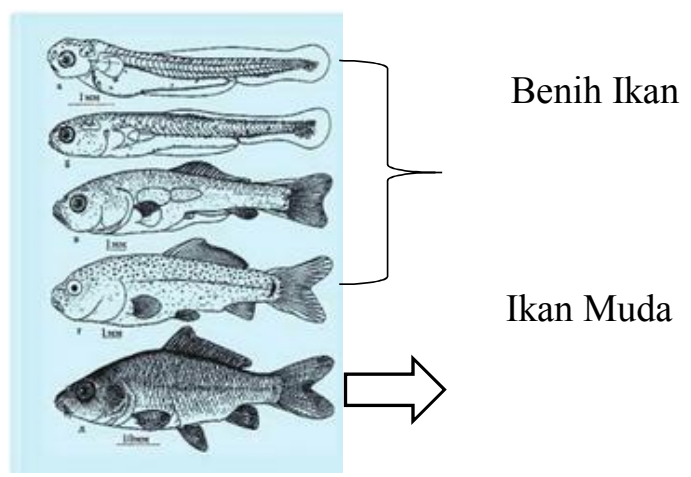

Gambar 1. Benih Ikan dan Ikan Muda

Benih harus dihitung untuk mengetahui jumlahnya. Perhitungan juga harus dilakukan dengan cepat dan tepat agar benih tidak menjadi lemah lalu mati. Dengan cara perhitungan yang benar, benih akan tetap segar.

\subsection{Mini Komputer}

Mini komputer adalah versi mainframe yang lebih kecil dan lebih lambat. Salah satu contohnya adalah Raspberry pi. Raspberry Pi 3 adalah generasi ketiga dari Raspberry (Anonim) pada Gambar 2. Merupakan pengganti dari Raspberry Pi 2 Model B pada bulan Februari 2016.

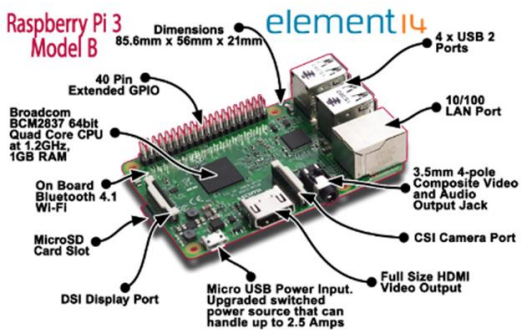

Gambar 2. Raspberry Pi3 Model B

\subsection{Image Processing}

Pengolahan citra atau Image Processing adalah suatu sistem dimana proses dilakukan dengan masukan (input) berupa citra (image) dan hasilnya (output) juga berupa citra (image). Citra atau image adalah angka, dari segi estetika, citra atau gambar adalah kumpulan warna yang bisa terlihat indah, memiliki pola, berbentuk abstrak dan lain sebagainya. Citra dapat berupa foto udara, penampang lintang (cross section) dari suatu benda, gambar wajah, hasil tomografi otak dan lain sebagainya.

\subsubsection{Grayscale Image}

Citra keabuan (grayscale image) memberi kemungkinan warna yang lebih banyak daripada citra biner. Format citra ini disebut skala keabuan karena pada umumnya warna yang dipakai adalah warna hitam sebagai warna minimal dan warna putih sebagai warna maksimalnya, sehingga disebut abuabu.

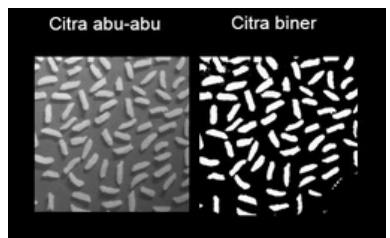

Gambar 3. Citra abu-abu dan citra biner

\subsubsection{Binary Inverted Threshold}

Binary Inverted Threshold adalah citra digital yang hanya memiliki dua kemungkinan nilai untuk setiap piksel. Biasanya dua warna yang digunakan untuk citra biner adalah hitam dan putih. Warna yang digunakan kebalikan dari Binary Threshold untuk obyek dalam gambar adalah warna latar depan (foreground) berwarna hitam, sedangkan sisanya dari gambar adalah latar belakang yang berwarna putih.

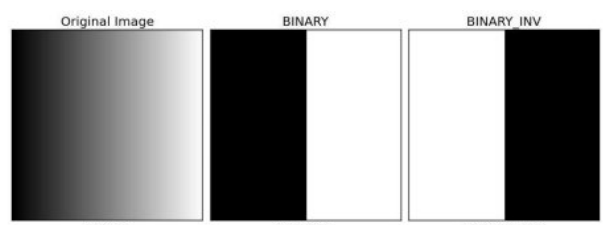

Gambar 4. Perbedaan Binary dan Binary Inverted Threshold

\subsubsection{Erosi Morphology}

Erosi merupakan proses penghapusan titiktitik objek (1) menjadi bagian dari latar (0), berdasarkan structuring element $S$ yang digunakan.

$$
E(A, S)=A \oplus S
$$




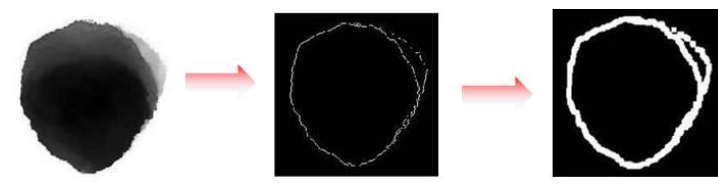

Gambar 5. Contoh erosi

\subsubsection{Dilasi Morphology}

Dilasi merupakan proses penggabungan titiktitik latar (0) menjadi bagian dari objek (1), berdasarkan structuring element $S$ yang digunakan.

$$
E(A, S)=A \oplus S
$$
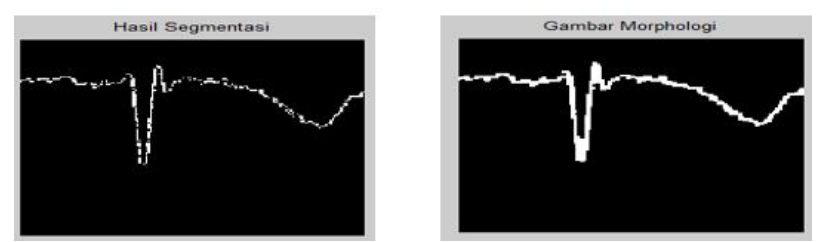

Gambar 6. Contoh Dilasi

\subsubsection{Connected Componnt Labeling (CCL)}

Connected Component Labeling adalah salah satu langkah yang paling penting dalam image processing dan pengenalan pola. Piksel yang berdekatan akan berbagi fitur yang sama. CCL adalah menemukan label yang unik untuk setiap element yang terhubung dalam input data.

\section{Metodologi Penelitian}

\subsection{Blok Diagram}

Pada perencanaan elektronik terlebih dahulu dibuat blok diagram pada Gambar 7 yang nantinya akan mempermudah mengetahui alur kerja dari alat penghitung ikan ini.

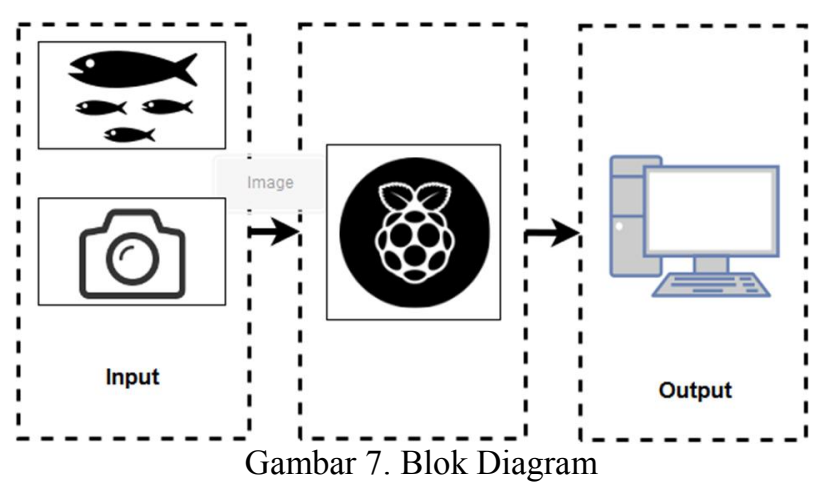

\subsection{Perancangan Sistem}

Tahapan Image Processing (Gambar 8) akan dijelaskan tiap point di bawah ini.

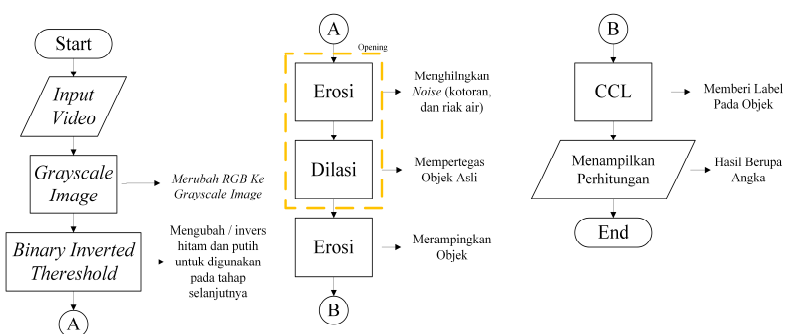

Gambar 8. Flowchart Umum Tahapan Image Processing

\section{Implementasi}

\subsection{Implementasi Antar Muka}

Pada Gambar 9 merupakan tampilan halaman depan, di mana kita dapat monitoring hasil perhitungan ikan. Tampilan pada halaman antar muka web yang berisi tingkat keakuratan perhitungan, kalibrasi, serta proses dari pengolahan citra.

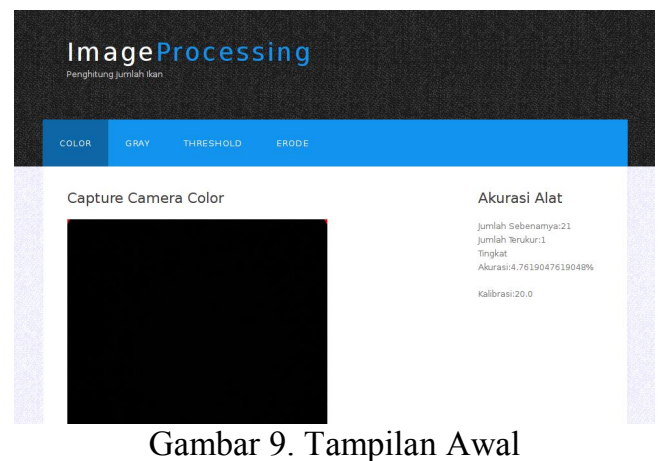

\subsection{Implementasi Alat}

Pengambilan citra benih ikan menggunakan sebuah alat untuk mempermudah pengambilan citra. Alat yang digunakan berupa wadah (Gambar 10) yang dirangkai dengan sebuah kamera pada bagian penutup box.

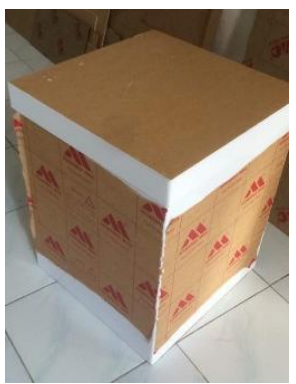


Gambar 10. Wadah Benih Ikan

\section{Pengujian}

\subsection{Uji Coba Fungsional}

Uji coba fungsional digunakan untuk mengetahui apakah sistem dibangun sesuai dengan yang dibutuhkan. Uji coba ini dilakukan menggunakan blackbox, karena pengujian ini lebih ditujukan untuk menentukan kesesuai antara kinerja sistem dengan daftar kebutuhan. Hasil uji coba fungsional dapat dilihat pada Tabel 1.

Tabel 1. Uji Coba Fungsional

\begin{tabular}{|c|c|c|c|c|c|}
\hline No & Case & Input & $\begin{array}{c}\text { Valida } \\
\text { si }\end{array}$ & Hasil Uji & Status \\
\hline \multirow[t]{2}{*}{1} & \multirow{2}{*}{$\begin{array}{l}\text { Jumlah } \\
\text { benih } \\
\text { sebenarn } \\
\text { ya }\end{array}$} & \multirow[t]{2}{*}{ Angka } & $\begin{array}{l}\text { Data } \\
\text { valid }\end{array}$ & $\begin{array}{l}\text { Data } \\
\text { ditampilkan }\end{array}$ & \multirow[t]{2}{*}{ Diterima } \\
\hline & & & $\begin{array}{l}\text { Data } \\
\text { invalid }\end{array}$ & $\begin{array}{l}\text { Data } \\
\text { ditampilkan } \\
\text { tapi } \\
\text { perhitungan } \\
\text { tidak sesuai }\end{array}$ & \\
\hline \multirow[t]{2}{*}{2} & \multirow[t]{2}{*}{$\begin{array}{l}\text { Threshol } \\
\text { d }\end{array}$} & \multirow[t]{2}{*}{ Angka } & $\begin{array}{l}\text { Data } \\
\text { valid }\end{array}$ & $\begin{array}{l}\text { Image } \\
\text { processing } \\
\text { dapat } \\
\text { diproses }\end{array}$ & \multirow[t]{2}{*}{ Diterima } \\
\hline & & & $\begin{array}{l}\text { Data } \\
\text { invalid }\end{array}$ & $\begin{array}{l}\text { Jika terlalu } \\
\text { tinggi dan } \\
\text { rendah } \\
\text { dapat } \\
\text { mempengar } \\
\text { uhi image } \\
\text { processing }\end{array}$ & \\
\hline
\end{tabular}

\subsection{Pengujian Sistem}

a. Case Pengujian Ikan Berwarna Cerah

Tabel 2. Uji Coba Perhitungan Pada Ikan Berwarna Cerah

\begin{tabular}{|c|c|}
\hline Case & Ikan Berwarna Cerah \\
\hline $\begin{array}{c}\text { Skenario } \\
\text { uji }\end{array}$ & $\begin{array}{c}\text { Website aktif, kamera dalam } \\
\text { keadaan aktif, dan box terdapat ikan } \\
\text { komet (cerah) }\end{array}$ \\
\hline $\begin{array}{c}\text { Hasil yang } \\
\text { diharapkan }\end{array}$ & $\begin{array}{c}\text { Kamera dapat mengambil objek, } \\
\text { menghitung, serta mengeluarkan } \\
\text { output hasil perhitungan }\end{array}$ \\
\hline
\end{tabular}

\begin{tabular}{|c|c|}
\hline Case & Ikan Berwarna Cerah \\
\hline $\begin{array}{c}\text { Hasil yang } \\
\text { terjadi }\end{array}$ & $\begin{array}{c}\text { Kamera dapat mengambil objek, } \\
\text { menghitung, serta mengeluarkan } \\
\text { output hasil perhitungan }\end{array}$ \\
\hline
\end{tabular}

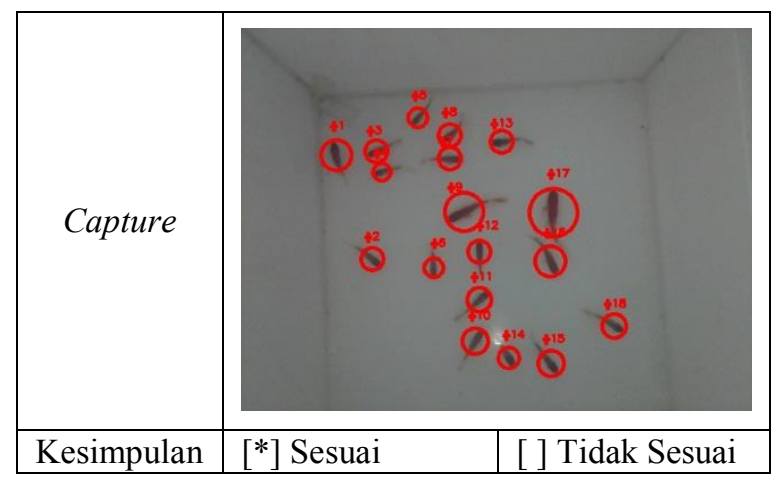

b. Case Pengujian Ikan Berwarna Gelap

Tabel 3. Uji Coba Perhitungan Pada Ikan Berwarna Gelap

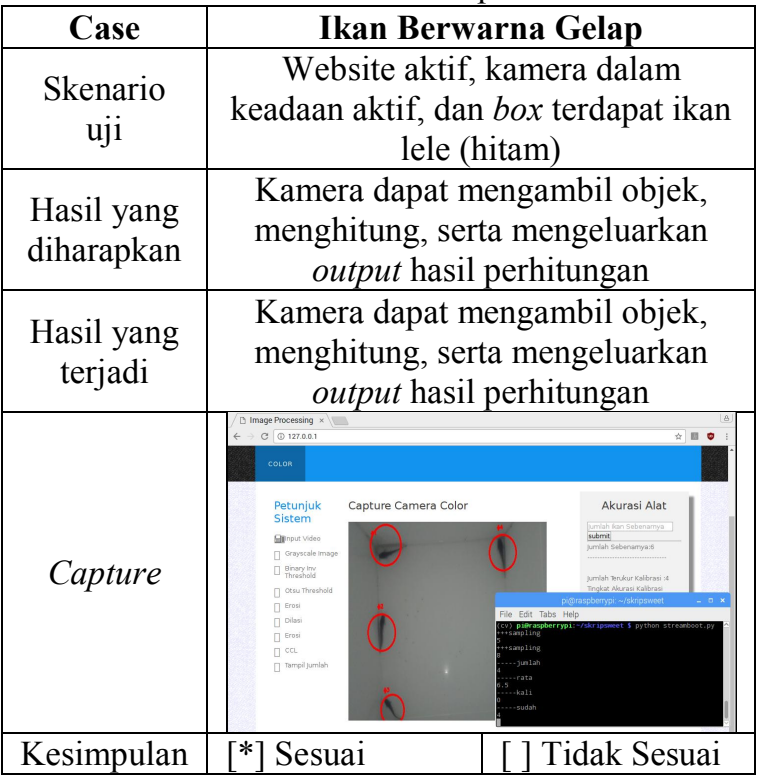

c. Case Pengujian Ikan Berwarna Putih

Tabel 4. Uji Coba Perhitungan Pada Ikan Berwarna Putih

\begin{tabular}{|c|c|}
\hline Case & Ikan Berwarna Putih \\
\hline Skenario uji & $\begin{array}{c}\text { Website aktif, kamera dalam } \\
\text { keadaan aktif, dan box terdapat ikan } \\
\text { koi (putih) }\end{array}$ \\
\hline $\begin{array}{c}\text { Hasil yang } \\
\text { diharapkan }\end{array}$ & $\begin{array}{c}\text { Kamera dapat mengambil objek, } \\
\text { menghitung, serta mengeluarkan } \\
\text { output hasil perhitungan }\end{array}$ \\
\hline
\end{tabular}




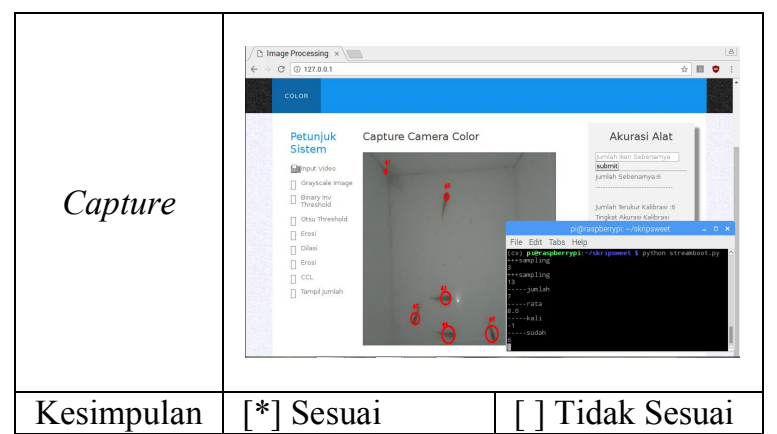

\subsection{Pengujian Akurasi Alat}

Pengujian akurasi alat digunakan untuk mengetahui seberapa akurat sistem dapat mendeteksi objek pada kondisi yang berbeda.

1. Jumlah Ikan $=20$ ekor

Tinggi Air $=5 \mathrm{~cm}$

Tabel 5. Uji Coba 20 Ekor Sebelum Kalibrasi

\begin{tabular}{|c|c|c|c|c|}
\hline 20 & $\begin{array}{c}\text { Nilai } \\
\text { Terukur }\end{array}$ & $\begin{array}{c}(\mathrm{Vi}- \\
\text { Mean })^{2}\end{array}$ & Stdv & $\mathbf{U a}$ \\
\hline & 11 & 81 & 4.02 & 1.797799 \\
\hline & 18 & 4 & 0.89 & 0.39802 \\
\hline & 16 & 16 & 1.78 & 0.79604 \\
\hline & 17 & 9 & 0.45 & 0.201246 \\
\hline & 16 & 16 & 1.78 & 0.79604 \\
\hline & 19 & 1 & 0.45 & 0.201246 \\
\hline Mean & 16.16666667 & & & \\
\hline Error & 3.833333333 & & & \\
\hline $\begin{array}{l}\text { Error } \\
\text { Relatif }\end{array}$ & 0.001916667 & & & \\
\hline
\end{tabular}

Tabel 6. Uji Coba 20 Ekor Setelah Kalibrasi

\begin{tabular}{|c|c|}
\hline NSK & NSK(pembulatan) \\
\hline 14.83333 & 15 \\
\hline 21.83333 & 22 \\
\hline 19.83333 & 20 \\
\hline 20.83333 & 21 \\
\hline 19.83333 & 20 \\
\hline 22.83333 & 23 \\
\hline Mean & 20 \\
\hline Error & 0 \\
\hline $\begin{array}{c}\text { rror } \\
\text { Relatif }\end{array}$ & 0 \\
\hline
\end{tabular}

2. Jumlah Ikan $=30$ ekor

Tinggi Air $=5 \mathrm{~cm}$

Tabel 7. Uji Coba 30 Ekor Sebelum Kalibrasi

\begin{tabular}{|c|c|c|c|c|}
30 & $\begin{array}{c}\text { Nilai } \\
\text { Terukur }\end{array}$ & $\begin{array}{c}\text { (Vi- } \\
\text { Mean }) 2\end{array}$ & Stdv & Ua \\
\hline & 24 & 36 & 2.68 & 1.198532 \\
\hline
\end{tabular}

\begin{tabular}{|l|c|c|c|c|}
\hline \multirow{2}{*}{30} & $\begin{array}{c}\text { Nilai } \\
\text { Terukur }\end{array}$ & $\begin{array}{c}(\mathbf{V i} \text { - } \\
\text { Mean } \mathbf{2}\end{array}$ & \multicolumn{1}{c|}{ Stdv } & Ua \\
\hline & 20 & 100 & 4.47 & 1.999045 \\
\hline & 20 & 100 & 4.47 & 1.999045 \\
\hline & 21 & 81 & 4.02 & 1.797799 \\
\hline & 20 & 100 & 4.47 & 1.999045 \\
\hline Mean & 21.5 & 36 & 2.68 & 1.198532 \\
\hline Error & 8.5 & & & \\
\hline $\begin{array}{l}\text { Error } \\
\text { Relatif }\end{array}$ & 0.002833333 & & & \\
\hline
\end{tabular}

Tabel 8. Uji Coba 30 ekor Setelah Kalibrasi

\begin{tabular}{|c|c|}
\hline NSK & NSK(pembulatan) \\
\hline 32.5 & 33 \\
\hline 28.5 & 29 \\
\hline 28.5 & 29 \\
\hline 29.5 & 30 \\
\hline 28.5 & 29 \\
\hline 32.5 & 33 \\
\hline Mean & 30 \\
\hline Error & 0 \\
\hline Error & 0 \\
\hline Relatif & \\
\hline
\end{tabular}

3. Jumlah Ikan $=40$ ekor

Tinggi Air $=5 \mathrm{~cm}$

Tabel 9. Uji Coba 40 Ekor Sebelum Kalibrasi

\begin{tabular}{|l|c|c|c|c|}
\hline 40 & $\begin{array}{c}\text { Nilai } \\
\text { Terukur }\end{array}$ & $\begin{array}{c}(\text { Vi- } \\
\text { Mean }) 2\end{array}$ & \multicolumn{1}{|c|}{ Stdv } & \multicolumn{1}{|c|}{ Ua } \\
\hline & 32 & 64 & 3.57 & 1.596553 \\
\hline & 30 & 100 & 4.47 & 1.999045 \\
\hline & 31 & 81 & 4.02 & 1.797799 \\
\hline & 35 & 25 & 2.24 & 1.001758 \\
\hline & 28 & 144 & 5.37 & 2.401537 \\
\hline & 29 & 121 & 4.92 & 2.200291 \\
\hline Mean & 30.83333333 & & & \\
\hline Error & 9.166666667 & & & \\
\hline $\begin{array}{c}\text { Error } \\
\text { Relatif }\end{array}$ & 0.002291667 & & & \\
\hline
\end{tabular}

Tabel 10. Uji Coba 40 Ekor Setelah Kalibrasi

\begin{tabular}{|c|c|}
\hline NSK & NSK(pembulatan) \\
\hline 41.16667 & 41 \\
\hline 39.16667 & 39 \\
\hline 40.16667 & 40 \\
\hline 44.16667 & 44 \\
\hline 37.16667 & 37 \\
\hline
\end{tabular}

\begin{tabular}{|c|c|}
\hline NSK & NSK(pembulatan) \\
\hline 38.16667 & 38 \\
\hline
\end{tabular}




\begin{tabular}{|c|c|}
\hline Mean & 40 \\
\hline Error & 0 \\
\hline $\begin{array}{c}\text { Error } \\
\text { Relatif }\end{array}$ & 0 \\
\hline
\end{tabular}

4. Jumlah Ikan $=50$ ekor

Tinggi Air $=5 \mathrm{~cm}$

Tabel 11. Uji Coba 50 Ekor Sebelum Kalibrasi

\begin{tabular}{|c|c|c|c|c|}
\hline 50 & $\begin{array}{c}\text { Nilai } \\
\text { Terukur }\end{array}$ & $\begin{array}{c}(V i- \\
\text { Mean }) 2\end{array}$ & Stdv & Ua \\
\hline & 40 & 100 & 4.47 & 1.999045 \\
\hline & 33 & 289 & 7.6 & 3.398823 \\
\hline & 38 & 144 & 5.37 & 2.401537 \\
\hline & 39 & 121 & 4.92 & 2.200291 \\
\hline & 37 & 169 & 5.81 & 2.598311 \\
\hline & 36 & 196 & 6.26 & 2.799557 \\
\hline Mean & 37.166666667 & & & \\
\hline Error & 12.83333333 & & & \\
\hline $\begin{array}{l}\text { Error } \\
\text { Relatif }\end{array}$ & 0.002566667 & & & \\
\hline
\end{tabular}

Tabel 12. Uji Coba 50 Ekor Setelah Kalibrasi

\begin{tabular}{|c|c|}
\hline NSK & NSK(pembulatan) \\
\hline 52.83333 & 53 \\
\hline 45.83333 & 46 \\
\hline 50.83333 & 51 \\
\hline 51.83333 & 52 \\
\hline 49.83333 & 50 \\
\hline 48.83333 & 49 \\
\hline Mean & 50 \\
\hline Error & 0 \\
\hline $\begin{array}{c}\text { Error } \\
\text { Relatif }\end{array}$ & 0 \\
\hline
\end{tabular}

\subsection{Analisis Hasil Uji Coba}

Berdasarkan hasil perhitungan nilai eror ratarata, maka dapat diambil data sebagai berikut.

Tabel 13. Hasil Perhitungan Pengujian

\begin{tabular}{|c|c|c|c|c|}
\hline $\begin{array}{c}\text { Jumlah } \\
\text { Ikan }\end{array}$ & $\begin{array}{c}\text { Rata } \\
\text { Tingkat } \\
\text { Akurasi } \\
\text { Sebelum } \\
\text { Kalibrasi } \\
(\%)\end{array}$ & $\begin{array}{c}\text { Error } \\
\text { Relatif (\%) }\end{array}$ & $\begin{array}{c}\text { Rata } \\
\text { Tingkat } \\
\text { Akurasi } \\
\text { Setelah } \\
\text { Kalibrasi } \\
(\%)\end{array}$ & $\begin{array}{c}\text { Error } \\
\text { Relatif } \\
(\%)\end{array}$ \\
\hline 20 & 99.99808333 & 0.001916667 & 100 & 0 \\
\hline 30 & 99.99716667 & 0.002833333 & 100 & 0 \\
\hline 40 & 99.99770833 & 0.002291667 & 100 & 0 \\
\hline 50 & 99.99743333 & 0.002566667 & 100 & 0 \\
\hline
\end{tabular}

Berdasarkan data hasil pengujian, menunjukkan nilai error terendah terdapat pada pengujian 20 ekor ikan. Hal ini disebabkan karena wadah box yang besar terhadap jumlah ikan yang sedikit dapat memperkecil kemungkinan terjadinya ikan menumpuk atau ikan yang terlihat menjadi satu pada saat pengambilan objek, sehingga hasil yang ditampilkan memiliki akurasi yang tinggi pada pengujian 20 ekor ikan.

Nilai tertinggi error terdapat ada hasil pengujian 30 ekor ikan, yaitu nilai persentase error rata-rata didapatkan nilai sebesar $0.0028333 \%$. Ini berarti nilai error cenderung lebih besar daripada proses pengujian yang lainnya bisa dikarenakan ikan yang saling menempel atau bertumpuk tergantung ikan tersebut. Hal ini menandakan untuk pengujian sejumlah 30 ekor memiliki akurasi yang cenderung lebih kecil dibandingkan pengujian sejumlah 50, karena perhitungan yang maksimal dibutuhkan nilai error yang kecil. Sehingga dapat diketahui bahwa perhitungan untuk jumlah ikan 50 ekor bisa dilakukan, namun tidak disarankan karena nilai error yang cenderung besar.

Sedangkan nilai error yang kecil dapat dilihat dari hasil pengujian pada 40 ekor ikan. Dibanding pada hasil pengujian yang lainnya pada pengujian berjumlah banyak, pengujian terhadap 50 dan 40 ekor ikan ini lebih kecil nilai error-nya yaitu memiliki nilai persentase error rata-rata sebesar $0.0025666 \%$ dan $0.00229 \%$. Sehingga hasil ini didapatkan lebih akurat daripada nilai 2 pengujian sebelumnya yaitu 20 dan 30 ekor. Maka, apabila dilakukan perhitungan ikan selanjutnya dapat disarankan untuk mengambil nilai maksimal sebesar 40 ekor ikan pada penelitian ini.

Alasan dalam pemilihan 40 ekor adalah peternak ikan membutuhkan perhitungan yang dapat menghitung 40 ekor secara cepat dan meninggalkan perhitungan manual atau perhitungan secara volume. Keberhasilan dalam perhitungan 40 ekor yaitu sebesar $99.9977 \%$ hanya dalam beberapa detik dibandingkan perhitungan manual yaitu selama 1 menit.

\section{Kesimpulan dan Saran}

\subsection{Kesimpulan}

Berdasarkan penelitian yang telah dilakukan penulis mengenai perhitungan benih ikan menggunakan raspberry pi, maka dapat diambil kesimpulan bahwa :

- Penelitian ini telah berhasil membuat sistem yang digunakan untuk menghitung objek menggunakan image processing secara realtime. Perangkat ini dapat diakses dari local area dikarenakan khusus digunakan dalam satu ruang lingkup saja.

- Sistem berjalan sesuai dengan yang diharapkan, yaitu mampu menghitung objek secara optimal sebesar 40 ekor ikan dengan persentase error 
rata-rata sebesar $0.00229 \%$ sehingga tingkat keberhasilan alat ini mencapai $99.9977 \%$.

Dengan adanya sistem ini diharapkan dapat mempermudah peternak ikan dan mempercepat proses dalam menghitung benih ikan. Kelebihan lainnya adalah tidak memerlukan ruang penyimpanan data yang besar.

\subsection{Saran}

- Memperbaiki image processing agar proses dari pengambilan gambar sampai hasil ditampilkan di website menjadi semakin cepat.

- Memperbaiki mekanisme alat sehingga mampu menghitung dalam jumlah yang banyak.

- Memperbaiki kualitas media dan menguji ketahanan media.

\section{Daftar Pustaka:}

S. Bonnie and P. Marion, "Designing Information System”, 1st ed. Jakarta : Elex Media Komputindo, 2008.

P.F. Aulia and M.M. Aminudin, "Implementasi Image Processing Pada Alat Penghitung Benih Ikan Portable Berbasis Embedded System", Laporan Akhir Program Studi Teknik Elektronika : Politeknik Negeri Malang, 2016.

A. Khairul and S. Toguan, "Mengenal \& Mengendalikan Predator Benih Ikan", 1st ed. Jakarta : Gramedia Pustaka Utama, 2008.

A. Usni and D.Deni, "Panduan Lengkap Benih Ikan Konsumsi", 1st ed. Jakarta : Penerbar Sadaya, 2013 
Volume 4, Edisi 1, November 2017

$\mathbf{8} \mid \mathrm{H}$ a 1 a $\mathrm{m}$ a $\mathrm{n}$ 